\title{
How well adapted are accounting students for Bologna? A comparative analysis of learning styles of Spanish social sciences students
}

\author{
José Luis Arquero (arquero@us.es) - orcid: 0000-0002-7086-8812 \\ Universidad de Sevilla (España)
}

Concepción Tejero Rioja (ctejero@uhu.es) - orcid: 0000-0002-2407-2178

Universidad de Huelva (España)

http://dx.doi.org/10.12795/EDUCADE.2011.i02.08

\begin{abstract}
Background - University education in Spain is facing a major change in order to converge with the rest of Europe. Among the challenges the new pedagogy is based upon three principles: (I) increased autonomy and involvement of students in their own learning process, (II) active teaching methods and (III) role of the teaching staff as a manager of stimulating learning environments. This new pedagogy added to the development of certain soft skills, demands from students certain personal characteristics.

Aims - The present paper compares the learning styles of Spanish university accounting students with colleagues in other social sciences degrees as well as the influence of several personal factors.

Instrument and Sample - The instrument used is the Grasha-Reichmann Student Learning Style Scale, and the sample is composed by 619 students enrolled in different degrees at the University of Huelva.

Results - Results indicate that accounting students present differences in learning styles in comparison with other social sciences students. Other differences were found associated with gender and age.
\end{abstract}

KEYWORDS: accounting education, learning styles, GRSLSS.

\section{INTRODUCTION}

Among the most publicised objectives of the Bologna process the Ministerio de Educación highlights the new pedagogic approach that "could transform our educational system based on teaching into one based on learning". This change requires of three prerequisites (MEC, 2005):

- $\quad$ Higher autonomy and involvement of students in their learning process.

- The use of active pedagogical methods including team work.

- The role of the teaching staff as a manager of challenging learning environments.

Two of these requisites are closely related with students' competencies. The new learning environment is expected to be much more flexible and adaptable to the students' needs. Students will have a higher level of independence and responsibility to design their own curriculum and to obtain the maximum benefit from the resources and activities at their disposal. However, it is also clear that, in order to make the best use of those resources, students should be able to be active participants, to be independent learners and to integrate into work teams. Conversely, the results of research focusing on educational needs in our area (Arquero, 2000, Arquero and Donoso, 2005, Dacko, 2006, Hassall et al. 2003) stressed that the development of certain non-technical skills should be included as educational objectives, among them: 
Artículo. Recibido: 22-12-09 - Versiones revisadas: 09-04-10; 05-07-10, Aceptado: 10-09-10

Licencia Creative Commons (CC) BY-NC-ND · Asociación Española de Contabilidad y Administración de Empresas - AECA

- $\quad$ Problem solving skills (complex and unstructured problems)

- $\quad$ Learning to learn

- Communication and team working skills

These skills appear to be essential for the proper development of the accountants' tasks and are highly valued in hiring and promoting decisions (Arquero, 2000), and are even more important in terms of career progression (Bhamornsiri and Guinn, 1991).

In this context certain characteristics (such as factors associated with learning styles) could act as facilitators or constraints for both the development of the skills indicated above and the pedagogical change (Alonso et al, 1997; Yazici, 2005; Zhang, 2002).

The present paper compares the learning styles of accounting students with other social sciences students also analyzing the influence of gender and age in the learning styles exhibited by students. The paper is structured as follows: The first section gives an overview of the current learning context and the expected change due to the Bologna process. The research study section presents the rationale for the present study, the objectives and the measures used; followed by the sample description and the results. Finally, the discussion of the results and their implications are presented.

\section{THE CURRENT LEARNING CONTEXT AND EXPECTED CHANGES}

Actual higher education for accounting and business related subjects in Spain can be described as follows. Educational methods are highly focused on lectures. Although more participant educational methods (such as work cases, group work, etc.) are used, the accomplishment of content coverage objectives leads to teacher centered methods, even in practical lessons 1. This context is most usual in first course subjects. In advanced courses, where active pedagogy is more suitable it is more frequent to find a mix of teaching methods combining lectures, work cases, team work, etc. Clear and physical separation of lectures (theoretical content, large classes) and seminars (practical content, smaller groups) is not frequent. Usually, the same instructor teaches the whole group theory and practice in the same classroom. Even when different teachers for theory and practice exist, it is not usual to split off groups into smaller seminars for practice.

The average number of hours of contact classes is quite high in comparison with UK or USA standards: the average (for all subjects) is 4-5 contact hours per day, which means 20-25 contact hours weekly, on a basis of 15 weeks per term, with two terms included. Accounting courses usually have a teaching load of 4-5 contact hours weekly. Tutorials are provided for students, but attendance, usually, is not compulsory. Students' attendance at classes is quite variable and depends upon the timetable of the specific group and the time of the year (it tends to become reduced at the end of the terms when exams dates are closer).

The assessment tends to rely heavily on final exams. Although other activities have influence on final grades, exams are usually the most relevant aspect in the assessment system.

\footnotetext{
1 An analysis of the pressures to introduce the development of non technical skills, and the resistance to such change, in higher education in Spain can be found at González, Arquero and Hassall (2009).
} 
In comparison with the present system, the expected Bologna scenario is quite different. The objective is to focus on students' work. Therefore, more time should be devoted to student-based activities which are different to contact classes. Although the number of credits will remain similar, it is expected that there will be a reduction of contact class time. The autonomous work of students will increase including team projects, presentations, etc. This will need a change in the teaching methods used, the classroom organisation and the course material. It is expected that attendance and tutorials will become much more important. Assessment system must be aligned with the new objectives, thus, projects, group working and individual work must be assessed in accordance with the time and work required from the students to accomplish such tasks.

\section{THE RESEARCH STUDY}

\subsection{RATIONALE FOR THE STUDY}

In this new environment students, in order to make the best use of the expected advantages, should be able to be active participants. That means learning to become independent learners and to integrate into work teams. An early diagnosis of the learning styles of students enables advance awareness of potential mismatches between students' present characteristics and future educational requirements. Thus enabling the opportunity to design instructional processes that in a first instance could accommodate students' actual profiles and afterwards could use the mismatch of styles in a creative and challenging way fostering the change in the desired direction.

In the same way that a deep approach to learning is key to achieve high learning outcomes such us analytical and conceptual thinking skills (Hall et al, 2004), meaningful learning (as described by Ausubel, 1968) will require students not to be avoidant, but active participants and to be able to interact with the contents in a complex way.

Regarding accounting education, the opinion of relevant stakeholders (AAA-AECC, 1990;: Arthur Andersen et al. 1989; IFAC, 2008, etc.) and results of research (Arquero, 2000; Hassall et al. 2003) indicate the importance of team working and the relevance of lifelong learning: collaborative and independent styles are associated with these desired outcomes. Educational context should, by filtering at entry level or encouraging change in the students, result in higher scores in participant, collaborative and independent styles and lower scores on avoidant and dependent styles.

\subsection{MEASURES: GRASHA-REICHMANN LEARNING STYLES SCALE}

There exist a large diversity of instruments (scales and inventories) devoted to the assessment and diagnosis of cognitive / problem solving / reasoning / learning styles. Those instruments, developed from different theories and approaches (reviews of literature can be found in Cooper, 2001, or Cassidy, 2004), also assess how individuals interact in certain social situations.

From this range of instruments the Student Learning Style Scale developed by Grasha and Reichmann (GRSLSS, Grasha, 1996) was found to best fulfil the requirements of the present research. Evolving from the 1974 first version which consisted of 90 items this scale focused on learning and preferences (Cassidy, 2004). As Jonassen and Grabowski (1993), state the learning style interaction model is centred on student preferences introducing social and affective dimensions in styles measurement. It is to be noted that preferences for styles are to some extent variable and responsive to contextual learning 
factors $^{2}$. The inventory (Grasha, 1996) used consisted of 60 items, to be answered in a 5 points Likert scale (ranging from 1: total disagreement to 5: total agreement; being 3 the neutral opinion) which provides six measures3:

- dependent-independent

- participant-avoidant

- collaborative - competitive

With the exception of the avoidant - participant scale which presents very high negative correlation coefficients; these measures should not be seen as bipolar dimensions (Grasha, 1996, 170).

The internal reliability measures provided by Yazici (2005) for a sample of higher education students in business related subjects ranged from 0.73 to 0.89 (using Cronbachs' alpha).

The relevance of this instrument can be explained as follows, that in order to be successful the pedagogical change requires from students to be participant, collaborative and to some extent, independent. In contrast highly dependent, avoidant, or highly competitive students do not present the needed attitudes for the changes to work properly. Also to develop lifelong learning skills students are required to present a low dependent profile and team working requires high collaborative style.

Due to confidentiality restrictions, a posteriori measures of academic performance could not be obtained to be paired with learning style scores. However, for entry level students we could obtain a measure of previous performance: the access to university grade. These previous measures of performance are highly correlated with subsequent grades (see, for instance, Arquero et al, 2009 and Guney, 2009) therefore they could be considered as an adequate proxy.

\subsection{OBJECTIVES}

The specific objectives of the present study could be described as follows:

In order to know if the accounting degree is attracting students presenting the adequate profile of learning styles, the main objective is to compare the learning styles exhibited by accounting students with their fellows at other social sciences degrees.

Gender and age appear to be associated with different learning styles (Arquero and Tejero, 2006; Grasha, 1996, 176) or learning approaches (Byrne et al, 2002; Hassall and Joyce, 2001). Male students tend to present lower participant, dependent and collaborative scores and higher avoidant, independent and competitive scores than female students in USA samples. Older students tend to present higher scores in independent and participant styles and younger students tend to be more avoidant and competitive. Also the changing nature of learning styles has been highlighted

\footnotetext{
2 As Grasha states (1996, 171), although students have certain preferences for styles, those preferences are often adapted responding to changes on the learning context. This idea of adaptation of learning style to contextual factors is not new; as Jackling (2005) notes, there is a substantial body of research, within the approaches to learning framework, on relations between students' perceptions of learning, learning environment, approaches to learning and learning outcomes.

${ }^{3}$ Generic characteristics of students presenting different learning style are presented in the appendix.
} 
above. The second objective is to test if there are differences in learning styles associated with relevant personal factors: age, gender and professional experience.

Learning styles are also associated with academic performance. Grasha (1996, 176) indicates that avoidant students obtain lower grades, whereas participant students tend to obtain higher grades. The third objective is to test if there are relationship between academic performance and learning styles.

\section{SAMPLE DESCRIPTION AND RESULTS}

The sample is composed of 619 students enrolled on several university degrees (see Table 1) ascribed as the "social sciences" area at the Universidad de Huelva4.

The age of the respondents ranged from 17 to 62 years old. The mean was 21.94; the median 21 , and $95 \%$ of the respondents were 27 or younger. In order to test differences ages were re-codified into 3 intervals: up to and including 19 years, from 20 to 23,24 or older. Of the respondents $64 \%$ were female, and $36 \%$ male. Students (only from courses higher than first, n: 444) were asked if they had relevant professional experience or did a placement period. Of these, 134 , around $30 \%$, indicated they had done so.

TABLE 1. SAMPLE BY DEGREE

\begin{tabular}{|l|c|c|}
\hline & $n$ & Percentage \\
\hline Accounting & 366 & 59.1 \\
\hline Other - Law & 99 & 16.0 \\
\hline $\begin{array}{l}\text { Other - Psychology and Learning } \\
\text { sciences }\end{array}$ & 154 & 24.9 \\
\hline Total & 619 & 100.0 \\
\hline
\end{tabular}

The questionnaires were administered at the beginning of the term during class time. As the attendance at classes during the first weeks is normally high this means non response bias became irrelevant.

Entry level students were asked to indicate the grade they obtained to access to the university. The average grade was 6.3 ranging from 4.75 to 9.12 (n: 162, standard deviation .883).

Table 2 presents the correlations between scores for the whole sample. The results obtained support the conclusions by Grasha (1996). A strong negative correlation was found between participant-avoidant styles scores and no significant correlations between independent - dependent and competitive - collaborative were found. It is interesting to note that dependent style is highly correlated with participant and collaborative styles and the two last styles are also inter-correlated.

To test the differences MANOVA analyses were performed. The score in each learning style was the variable to be explained with the different factors (age, degree, gender and professional experience). Given that the number of cases needed to perform correctly a MANOVA analysis with all the factors at the same time is quite high, a series

\footnotetext{
${ }^{4}$ In the Universidad de Huelva, a specific accounting degree did not exist when the study was done. Several universities are offering the new degree in finance and accounting from 2009-2010 course. To date, business administration, with a high accounting weight, is the most widespread degree for management, finance and accounting in higher education. Therefore accounting students are students enrolled at compulsory accounting modules at the business administration and management degree.
} 
José Luis Arquero, Concepción Tejero How well adapted are accounting students for Bologna?

of analyses was performed discarding non relevant factors and entering new ones. The results include only significant factors. 
José Luis Arquero, Concepción Tejero

How well adapted are accounting students for Bologna?

TABle 2. Correlations betWeEn SCORES

\begin{tabular}{|l|l|r|r|r|r|r|}
\hline \multicolumn{2}{|l|}{} & Avoidant & Collaborative & Dependent & Competitive & Participant \\
\hline Independent & Coef. &, $081\left(^{*}\right)$ &, $153\left(^{* *}\right)$ &,- 007 &, $135\left(^{* *}\right)$ &, $152\left(^{* *}\right)$ \\
\hline & Sig. (2-tailed) &, 047 &, 000 &, 873 &, 001 &, 000 \\
\hline & $\mathrm{N}$ & 606 & 605 & 606 & 603 & 605 \\
\hline Avoidant & Coef. & &,$- 183\left(^{* *}\right)$ &,$- 102\left(^{*}\right)$ &, 058 &,$- 494\left(^{* *}\right)$ \\
\hline & Sig. (2-tailed) & &, 000 &, 012 &, 155 &, 000 \\
\hline & $\mathrm{N}$ & & 610 & 611 & 608 & 610 \\
\hline Collaborative & Coef. & & &, $285\left(^{* *}\right)$ &, 034 &, $419\left(^{* *}\right)$ \\
\hline & Sig. (2-tailed) & & &, 000 &, 409 &, 000 \\
\hline & $\mathrm{N}$ & & & & 606 & 609 \\
\hline Dependent & Coef. & & & &, $179\left(^{* *}\right)$ &, $416\left(^{* *}\right)$ \\
\hline & Sig. (2-tailed) & & & &, 000 &, 000 \\
\hline & $\mathrm{N}$ & & & & & 607 \\
\hline Competitive & Coef. & & & & &, $200\left(^{* *}\right)$ \\
\hline & Sig. (2-tailed) & & & & &, 000 \\
\hline & $\mathrm{N}$ & & & & & 606 \\
\hline
\end{tabular}

* Pearson Correlation is significant at the 0.05 level (2-tailed). ${ }^{* *}$ Pearson Correlation is significant at the 0.01 level (2-tailed).

There are significant differences in independent style scores due to gender and degree (Tables $3 a$ and $3 b$ ). Male students tend to present higher scores in independent style than their female colleagues. Students enrolled in other social sciences degrees show higher independent style scores than accounting students. No significant differences were found due to age or professional experience.

TABle 3A. INDEPENDENT STYLE. DesCRIPTIVES BY DEGREe AND GENDER

\begin{tabular}{|c|c|c|c|}
\hline & Mean & STD & $N$ \\
\hline Accounting - Male & 3.35 & .52 & 143 \\
\hline Accounting - Female & 3.19 & .43 & 221 \\
\hline Others - Male & 3.54 & .53 & 73 \\
\hline Others - Female & 3.42 & .53 & 168 \\
\hline
\end{tabular}

TABle 3B. Difference Of MEANS teSt (MANOVA). INDEPENDENT STYLE by DEGREe AND GeNDER

\begin{tabular}{|l|r|}
\hline MANOVA & Sig. Of F \\
\hline Degree & .000 \\
\hline Gender & .001 \\
\hline
\end{tabular}

There are slight differences in dependent style score between accounting students and others (accounting students tend to be more dependent) but such differences are not statistically significant. Gender, again, and age appear to be associated with significant differences in this style (Tables $4 a$ and $4 b$ ).

TABle 4A. Dependent Style. Descriptives by age AND Gender

\begin{tabular}{|c|c|c|c|}
\hline & Mean & STD & $N$ \\
\hline Till 20-Male & 3.97 & .361 & 80 \\
\hline Till 20 - Female & 4.12 & .352 & 154 \\
\hline 23 or older - Male & 3.81 & .495 & 81 \\
\hline 23 or older - Female & 4.03 & .350 & 118 \\
\hline
\end{tabular}


TAble 4b. Difference of MeAns test (MANOVA). Dependent Style by AGe AND Gender

\begin{tabular}{|l|r|}
\hline MANOVA & \multicolumn{1}{|c|}{ Sig. of $F$} \\
\hline Age & .002 \\
\hline Gender & .000 \\
\hline
\end{tabular}

Older students tend to show lower dependent styles scores. Males consistent with former results, show lower dependent style score than females. No significant differences were found due to professional experience.

Avoidant and participant styles are key factors for the success of the forthcoming changes. Gender and degree (see Tables $5 a$ and $5 b$ ) are factors associated with differences in avoidant style.

TAble 5A. Avoidant StYle. Descriptives by Degree AND Gender

\begin{tabular}{|c|c|c|c|}
\hline & Mean & STD & $N$ \\
\hline Accounting - Male & 2.81 & .45 & 143 \\
\hline Accounting - Female & 2.61 & .44 & 221 \\
\hline Others - Male & 2.97 & .59 & 75 \\
\hline Others - Female & 2.68 & .47 & 171 \\
\hline
\end{tabular}

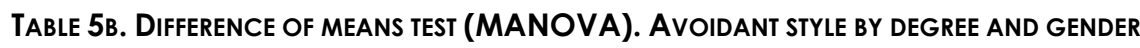

\begin{tabular}{|l|r|}
\hline MANOVA & Sig. of $F$ \\
\hline Degree & .064 \\
\hline Gender & .000 \\
\hline
\end{tabular}

In general terms, males tend to be more avoidant than females. Students enrolled in accounting subjects show lower levels of avoidant style than their colleagues in other degrees.

For participant style, MANOVA analysis indicates significant differences due to gender and age (Tables 6a and 6b).

Female students are much more participative than their male colleagues. This difference is highly significant. The influence of age is more complex. For accounting students, the score in participant style diminishes with age. Older students tend to be less participative. However, for other degrees students older students tend to be more participant.

Table 6a. Participant Style. Descriptives by age, degree AND Gender

\begin{tabular}{|c|c|c|c|}
\hline & Mean & STD & $N$ \\
\hline Till 20 - Accounting - Male & 3.53 & .53 & 77 \\
\hline Till 20 - Accounting - Female & 4.03 & .50 & 133 \\
\hline Till 20 - Others - Male & 3.20 & .61 & 3 \\
\hline Till 20 - Others - Female & 3.69 & .54 & 21 \\
\hline 23 or older - Accounting - Male & 3.34 & .65 & 29 \\
\hline 23 or older - Accounting - Female & 3.73 & .52 & 42 \\
\hline 23 or older - Others - Male & 3.32 & .54 & 50 \\
\hline 23 or older - Others - Female & 3.95 & .54 & 77 \\
\hline
\end{tabular}


TAble 6b. Difference of means test (MANOVA). Participant Style by AGe, Degree AND Gender

\begin{tabular}{|l|r|}
\hline MANOVA & Sig. of $F$ \\
\hline Age & .047 \\
\hline Degree & n.s. \\
\hline Gender & .000 \\
\hline
\end{tabular}

Female students show a less competitive learning style than male students (Tables 7a and $7 \mathrm{~b}$ ). Accounting students are also more competitive than students at other degrees.

TAble 7A. Competitive style. Descriptives by degree AND Gender

\begin{tabular}{|l|r|r|r|}
\hline & \multicolumn{1}{|l|}{ Mean } & STD & N \\
\hline Accounting - Male & 2.71 & .68 & 143 \\
\hline Accounting - Female & 2.46 & .57 & 221 \\
\hline Others - Male & 2.41 & .63 & 75 \\
\hline Others - Female & 2.32 & .63 & 167 \\
\hline
\end{tabular}

TAble 7b. Difference of means test (MANOVA). Competitive Style by Degree AND Gender

\begin{tabular}{|l|r|}
\hline MANOVA & \multicolumn{1}{|c|}{ Sig. of $F$} \\
\hline Degree & .000 \\
\hline Gender & .001 \\
\hline
\end{tabular}

Gender, degree and professional experience are related with differences in collaborative style (Tables $8 a$ and 8b).

Table 8a.Collaborative style. Descriptives by degree Gender and Prof. experience.

\begin{tabular}{|l|r|r|r|}
\hline & Mean & STD & N \\
\hline Accounting - Male - no exp & 3.37 & .59 & 65 \\
\hline Accounting - Male - exp & 3.32 & .67 & 9 \\
\hline Accounting - Female - no exp & 3.62 & .53 & 102 \\
\hline Accounting - Female - exp & 3.66 & .33 & 17 \\
\hline Others - Male - no exp & 3.58 & .61 & 47 \\
\hline Others - Male - exp & 3.70 & .51 & 28 \\
\hline Others - Female - no exp & 3.77 & .57 & 88 \\
\hline Others - Female - exp & 3.94 & .59 & 78 \\
\hline
\end{tabular}

TABle 8B. Difference Of MeANS test (MANOVA). Collaborative Style by DegreE GENDER AND PROF. EXPERIENCE

\begin{tabular}{|l|r|}
\hline MANOVA & Sig. of $F$ \\
\hline Degree & .000 \\
\hline Gender & .000 \\
\hline Prof. experience & .066 \\
\hline
\end{tabular}

In general terms, female students tend to be more collaborative than their male colleagues. Accounting students tend to be less collaborative than other degree students and professional experience tends to have a positive influence in collaborative style.

Results of the correlation analysis between styles scores and entry level grade support previous findings by Grasha. There exist a relationship between avoidant and collaborative styles and grades (Table 9). 
TABle 9. Correlation ANALysis betWeen entry LeVel GRADE AND StYles SCORES.

\begin{tabular}{|c|c|c|c|c|c|c|}
\hline & Independent & Avoidant & Collaborative & Dependent & Competitive & Participant \\
\hline $\begin{array}{c}\text { Pearson } \\
\text { Corr. Coef. }\end{array}$ & 0.093 & -0.254 & 0.041 & 0.068 & -0.044 & 0.289 \\
\hline $\begin{array}{c}\text { Sig. (2 } \\
\text { tailed) }\end{array}$ & n.s. & 0.001 & n.s. & n.s. & n.s. & 0.000 \\
\hline
\end{tabular}

$\mathrm{N}: 162$

students showing higher levels of avoidant style tends to obtain lower grades and students showing higher levels of collaborative style tend to obtain higher grades at a significant level (correlations $\mathrm{p}<1 \%$ ).

\section{DISCUSSION}

The adaptation of the higher education system to the Bologna requirements demands a deep pedagogical change towards more active and participant learning and teaching methods. Obviously this demands efforts and changes from both students and teaching staff. Also students should posses (or develop) certain characteristics in order to obtain the advantages of the new system.

Among the personal characteristics that students should develop in order to better take advantage of the Bologna educational context and also to improve throughout the educational process are:

- Ability to work, and learn, in an autonomous way

- Ability to actively participate in the learning process

- Team-working skills

In terms of the Grasha-Reichmann learning styles inventory, students should be independent, participant and collaborative.

Compared with the students that enrolled in other social sciences degrees, accounting students are less independent and more dependent. This is indicative of a higher difficulty to work and learn in an autonomous way than their colleagues. Dependent students prefer teacher-centred classroom methods and show little intellectual curiosity. Therefore, pedagogy relying upon autonomous work is likely to be less successful in accounting students than in other degrees students. Highly dependent students are more likely to take a surface approach to learning and do not perform well in complex tasks. Given that the ability to solve complex problems is one of the capabilities required from accounting students in the opinion of the relevant stakeholders these results are constraints that need to be taken into account.

The analysis of the scores also indicated that accounting students are more competitive. Competitive style is not good or bad itself. However competitive students prefer teaching centred instruction. Therefore they are not expected to be comfortable with student centred pedagogy or working in teams and sharing the grade with other members of the group. It is to be noted that the development in participant style is worrying. Whilst students in other degrees tend to score higher in participant style as they become older; accounting students tend to present lower scores. That means that accounting students (in contrast to other students in our sample, and Grasha's results with other samples) felt less comfortable collaborating with other students in projects, groups discussions etc, as they become older. This is an interesting result and needs to be studied in depth because learning styles are responsive to educational context. A plausible explanation is that previous educational experiences developed this move to a more individualistic view of education and learning. In this case the development of 
the scores is the opposite of that intended according to the stated aims of the required educational change.

No differences were found between accounting and other degrees students in participant style. Finally accounting students score lower in avoidant style than their colleagues the only learning style in which this group perform better than the other students.

Gender appears to be deeply related with differences in learning styles. Female students are less independent and more dependent than male students which could be a handicap for autonomous learning. However female students are less avoidant and more collaborative, which is indicative of a higher active involvement with the learning process and these are styles associated with higher grades. Also female students are more participative and less competitive than male students. This result indicates that female students may be more comfortable with the forthcoming scenario: active pedagogy based upon group working.

\section{IMPLICATIONS}

With the exception of avoidant styles students choosing other social sciences degrees seem to present a profile of learning styles that have a better fit with the Bologna requirements. The main implications for Universities are to establish entry level requirements that generate an adequate profile for the students entering this degree. Secondly better information (about the professional profiles and characteristics to succeed in higher education) should also be provided to future university students.

The results obtained on the development of a collaborative style for accounting students may be due to conflicting messages. Explicitly students are told to collaborate and work into teams but it seems that their actual experiences lead them to be less collaborative as they progresses in the university career. Incoherencies between explicated educational aims and assessment schemes could have a very negative impact in terms of the desired outcomes. Students tend to do what is rewarded not what they are told is the desired behaviour. Therefore Universities must pay attention to the coherence between educational goals, pedagogy, and assessment systems.

\section{LIMITATIONS AND EXTENSIONS}

The sample is obtained from one university. In order to guarantee the generalization of the results, a wider sample (more universities and/or cohorts of students) will be needed.

As possible extensions of the present work the following could be highlighted: a deep understanding of the causes of the observed development in the learning styles, analysing contextual and pedagogy-related factors and the potential relationship between learning styles and other performance indicators.

\section{REFERENCES}

Accounting Education Change Commission. [1990]: Position Statement No. 1. Objectives of Education for Accountants. Sarasota, AAA-AECC.

Alonso, C.M., GAllego, D.J. AND HONEY, P. [1997]: Los estilos de aprendizaje, procedimientos de diagnóstico y mejora. Mensajero. Bilbao.

ARQUERO, J.L. [2000]: Capacidades no técnicas en el perfil profesional en contabilidad: las opiniones de docentes y profesionales. Revista Española de Financiación y Contabilidad. XXIX, 103, 149-172 
ARQUERO, J.L., AND DONOSO, J.A. [2005]: "Diagnóstico del perfil profesional demandado para los egresados en las titulaciones del área financiero- contable". En Acreditación, Certificación e Innovación. 31-44. Instituto de Ciencias de la Educación, Universidad de Sevilla.

ARquero, J.L., AND TEJeRO, C. [2006]: Estilos de Aprendizaje y Tolerancia a la Ambigüedad de los Estudiantes Universitarios. Diagnóstico y Reflexiones Ante el Eees. Revista de Enseñanza Universitaria. Vol. 28, 7-17.

ARQUeRO, J.L.; BYRNE, M.; FLOOD, B. AND GONZÁLEZ, J.M. [2009]: Motives, Expectations, Preparedness and Academic Performance: a Study of Students of Accounting at a Spanish University. Spanish Accounting Review - Revista de Contabilidad. $12,2,95-116$.

ARTHUR ANDERSEN AND Co., [1989]: Perspectives on Education: Capabilities for Success in the Accounting Profession. New York.

AusuBEL, D. [1968]: Educational Psychology: A cognitive view. Holt, Rinehart and Winston.

BHAMORNSIRI, D AND GUINN, R.E. [1991]: The road to partnership in the 'Big Six' firms: implications for accounting education. Issues in Accounting Education. 6, 1, 9 24.

BYRNE, M.; FLOOD, B. AND WILLIS, P. [2002]: The relationship between learning approaches and learning outcomes: a study of Irish accounting students. Accounting Education. An International Journal. 11, 1, 27-42.

CASSIDY, S. [2004]: Learning Styles: An overview of theories, models and measures. Educational Psychology. 24,4, 419-444.

COOPER, S.S. [2001]: Learning Styles: Disponible en www.konnections.net/lifecircles /learningstyles.htm

DACKO, S.G. [2006]: "Developing the Top Five Skills within an MBA Programme: Implications for Management Educators". The International Journal of Management Education, 13, 2, pp. 21-31.

González González, J.M.; ARQuero, J.L. AND Hassall, T. [2009]: Pressures and Resistance to the Introduction of Skills in Business Administration and Accounting Education in Spain: a New Institutional Theory Analysis. Journal of Vocational Education and Training. 61, 1, 85-102.

GRASHA, A. [1996]: Teaching with Style. A practical guide to enhancing learning by understanding teaching and learning style. Pittsburgh, PA: Alliance Publishers.

GUNEY, Y. [2009]: Exogenous and Endogenous Factors Influencing Students' Performance in Undergraduate Accounting Modules. Accounting Education, 18, 1, 51-73.

HASSALL, T AND JOYCE, J [2001]: Approaches to learning of management accounting students. Education + Training. 43, 3, 145-152.

Hassall, T; JoYCE, J; ARQUero, J.L. AND Donoso, J.A. [2003]: The Vocational Skills Gap For Management Accountants: The Stakeholders Perspectives. Innovations in Education and Teaching International. Vol. 40-1. Pp. 78-88.

INTERNATIONAL FEDERATION OF ACCOUNTANTS. International Accounting Education Standards Board. [2008]: International education standards 1 - 8. N.Y., IFAC.

JACKLING, B. [2005]: Perceptions of the Learning Context and Learning Approaches: Implications for Quality Learning Outcomes in Accounting. Accounting Education: An International Journal. 14, 3, 271-291.

JONASSEN, D.H. AND GRABOWSKI, B.L. [1993]: Handbook of international differences, learning and instruction. Hillsdale. Lawrence Erlbaum assoc.

MINISTERIO DE EDUCACION Y CIENCIA. [2005]: Espacio Europeo de Educación Superior. MEC.

YAzlCl, H.J. [2005]: A study of collaborative learning style and team learning performance. Education + training. 47, 3, 216-229.

ZHANG, L. [2002]: Thinking styles: their relationships with modes of thinking and academic performance. Educational Psychology, 22, 3, 331-348. 


\section{Appendix: Learning Styles Explained}

\begin{tabular}{|c|c|}
\hline Participant & Avoidant \\
\hline $\begin{array}{l}\text { Good citizens in class. Enjoy going to class and } \\
\text { take part in as much of the course activities as } \\
\text { possible. Typically eager to do as much of the } \\
\text { required and optional course requirements as they } \\
\text { can. } \\
\text { Classroom Preferences. Lectures with discussion. } \\
\text { Opportunities to discuss material. Class reading } \\
\text { assignments. Teachers who can analyze and } \\
\text { synthesize information well. }\end{array}$ & $\begin{array}{l}\text { Not enthusiastic about learning content and } \\
\text { attending class. Do not participate with students } \\
\text { and teachers in the classroom. They are } \\
\text { uninterested and overwhelmed by what goes on in } \\
\text { class. } \\
\text { Generally turned off by most classroom activities. } \\
\text { Would prefer no tests / Pass-fail grading systems. } \\
\text { Does not like enthusiastic teachers. Does not want } \\
\text { to be called on in class. }\end{array}$ \\
\hline Collaborative & Competitive \\
\hline $\begin{array}{l}\text { Typical of students who feel they can learn by } \\
\text { sharing ideas and talents. They cooperate with the } \\
\text { teacher and like to work with others. } \\
\text { Classroom Preferences } \\
\text { Lectures with small group discussions. Small } \\
\text { seminars. Student designed aspects of courses. } \\
\text { Group projects. }\end{array}$ & $\begin{array}{l}\text { Students who learn material in order to perform } \\
\text { better than others in the class. Believe they must } \\
\text { compete with other students in a course for the } \\
\text { rewards that are offered. Like to be the centre of } \\
\text { attention and to receive recognition for their } \\
\text { accomplishments in class. } \\
\text { Classroom Preferences. Become a group leader in } \\
\text { discussions. Teacher-centred instructional } \\
\text { procedures. Singled out in class for doing a good } \\
\text { job. Class activities where they can do better than } \\
\text { others. }\end{array}$ \\
\hline Dependent & Independent. \\
\hline $\begin{array}{l}\text { Show little intellectual curiosity and who learn only } \\
\text { what is required. View teacher and peers as } \\
\text { sources of structure and support and look to } \\
\text { authority figures for specific guidelines on what to } \\
\text { do. } \\
\text { Clear deadlines and instructions for assignments. } \\
\text { Teacher-centred classroom methods. As little } \\
\text { ambiguity as possible in all aspects of course. }\end{array}$ & $\begin{array}{l}\text { Students who like to think for themselves and are } \\
\text { confident in their learning abilities. Prefer to learn } \\
\text { the content that they feel is important and would } \\
\text { prefer to work alone on course projects than with } \\
\text { other students. } \\
\text { An independent learner likes a maximum of } \\
\text { choice and flexibility, and a minimum of structure } \\
\text { and form in their learning environment. } \\
\text { Independent learners like to be in control of their } \\
\text { learning situations, }\end{array}$ \\
\hline
\end{tabular}

Source: Cuesta College (http://library.cuesta.cc.ca.us/distance/index.htm) 